\title{
PENGGUNAAN RADIOGRAF GIGI UNTUK KEPENTINGAN IDENTIFIKASI FORENSIK
}

Sita Rose Nandiasa*, Bramma Kiswanjaya ${ }^{* *}$, Mindya Yuniastuti ${ }^{* * *}$

\section{Keywords:}

forensic identification, dental radiographic

\section{ABSTRACT}

Background: Tooth has a unique characteristic. Teeth often used for forensic identification especially when the other parts of the body could not gave a difference feature used for identification.

Discussion: Tooth is part of the body known for its resistant against external influence making it as an important primary identifier. Dental radiographic can act as a helpful tool in identification process to compare antemortem and postmortem data. Radiograph can give a detail features from the teeth and their surroundings, especially digital radiograph so it can ease the identification process.

Conclusion : forensic identification using radiograph can be trusted.

\section{PENDAHULUAN}

Identifikasi forensik dilakukan terhadap jenazah yang tidak diketahui identitasnya baik akibat kejadian bencana massal, kecelakaan, pembunuhan, bunuh diri maupun kejadian lainnya ${ }^{1}$. Metode identifikasi menggunakan gigi dinilai sangat penting, berbeda halnya dengan jaringan lunak. Jaringan lunak seperti sidik jari dan DNA mudah mengalami kerusakan sehingga metode penilaian visual dan pemeriksaannya seringkali tidak dapat digunakan ${ }^{1,2}$. Penentuan identitas dapat diperoleh melalui perbandingan antemortem dan postmortem tampilan unik gigi $^{2,3}$. Perbandingan antemortem dengan postmortem menggunakan alat bantu radiograf gigi dinilai akurat dan terpercaya ${ }^{4}$.

\section{DISKUSI}

Identifikasi forensik adalah sebuah upaya kerjasama dan koordinasi aparat penegak hukum, patologi forensik, dokter gigi forensik, antropologi forensik, ahli ilmu hukum pidana dan spesialisasi terkait lain ${ }^{5}$. Identifikasi korban yang tidak diketahui identitasnya wajib dilakukan sebagaimana yang telah diamanatkan di dalam Undang-Undang Kesehatan Nomor 36 Tahun $2009^{6}$. Prosedur identifikasi dilakukan terhadap korban bencana alam banjir dan tanah longsor, kecelakaan lalu lintas, terorisme, kebakaran, kecelakaan kerja, dll. Identifikasi penting untuk dilakukan terkait pelaksanaan penyelidikan kasus kriminal, penentuan tatacara prosesi pemakaman, pembayaran asuransi kematian, dll 1,5,7,8.

Metode identifikasi forensik dibagi menjadi metode identifikasi primer dan sekunder. Identifikasi primer (DNA, gigi dan sidik jari) adalah metode identifikasi ilmiah yang mampu bertahan secara global dan telah terbukti sebagai metode identifikasi yang efektif ${ }^{9}$. DNA dan sidik jari seringkali tidak dapat digunakan apabila telah terjadi kerusakan berat dan meluas terhadap jaringan lunak korban

\footnotetext{
*Magister Program, Departement of Oral Biology-Forensic Dentistry, Faculty of Dentistry, Universitas Indonesia **Departement of Dental Radiology, Faculty of Dentistry, Universitas Indonesia

${ }^{* * *}$ Departement of Oral Biology, Faculty of Dentistry, Universitas Indonesia
}

Korespondensi: sr.nandiasa@gmail.com 
seperti pada kasus terbakar, skeletonisasi dan dekomposisi. Jaringan pada tubuh yang keras seperti gigi sangat dibutuhkan terkait kendala tersebut ${ }^{2,3,10}$. Jaringan gigi dilapisi oleh materi anorganik kristal hidroksiapatit sehingga resisten terhadap beragam jenis pengaruh eksternal, iritasi mekanik, termal dan kimia ${ }^{8,11}$.

Perbandingan gigi menggunakan radiograf untuk kepentingan identifikasi dinilai akurat dan terpercaya ${ }^{4,12}$. Radiograf gigi pertama kali digunakan dalam proses identifikasi pada tahun 1943. Semenjak saat itu radiograf gigi telah banyak digunakan dalam proses identifikasi ${ }^{13}$. Radiograf intraoral periapikal dengan teknik paralel dan biseksi dan bitewing adalah dua teknik radiograf intraoral yang umum digunakan dalam proses identifikasi yaitu untuk menghasilkan radiograf postmortem. Gambaran radiografis dengan karakteristik visual dan geometris yang baik mampu dihasilkan oleh kedua teknik tersebut 14. Radiograf intraoral adalah alat identifikasi yang baik sebagaimana telah disebutkan dalam penelitian Balagopal. Balagopal melakukan perbandingan radiograf intraoral antemortem dengan postmortem dimana pemeriksaan dilakukan oleh pengamat yang tidak berpengalaman, dengan hasil berupa sensitivitas sebesar 0,877 , spesifisitas sebesar 0,734 dan akurasi sebesar $0,816^{4}$.

Teknik pemeriksaan radiografis saat ini terbagi menjadi dua berdasarkan cara pemrosesan gambar yaitu teknik konvensional dan digital, namun teknik digital dinilai lebih unggul. Perangkat radiografi digital terdiri atas komputer beserta sistem perangkat keras dan lunak, media pencetak gambar, reseptor gambar dan analog-to-digital converter (ADC). Keunggulan teknik radiografi digital seperti kecepatan pemrosesan hasil radiograf, tampilan radiograf yang dapat dilihat secara langsung pada layar komputer, pemakaian berulang film, serta aplikasi penyesuaian kecerahan, kontras, densitas, ketajaman, magnifikasi dan warna yang tersedia pada perangkat lunak radiograf digital dinilai sangat memudahkan proses identifikasi ${ }^{15-17}$.

Identifikasi individu melalui radiograf gigi dilakukan dengan membandingkan tampilan antemortem dengan postmortem seperti bagian anatomis normal gigi dan jaringan sekitar, kondisi patologis, restorasi, onlay, crown, implant, pengisian saluran akar, morfologi akar dan makota, ukuran gigi, rotasi, diastema, jaringan periodontal dan kondisi soket paska ekstraksi 4,12,13,18. Melalui perbandingan tersebut dapat diketahui radiograf gigi yang dibandingkan berasal dari individu yang sama atau tidak ${ }^{13}$. Tahap perbandingan radiograf gigi antemortem dengan postmortem antara lain ${ }^{18}$ :

1. Pemeriksaan kualitas, tipe dan waktu pengambilan radiograf gigi antemortem.

2. Pemeriksaan spesimen postmortem dan duplikasi area of interest yang terlihat pada radiograf antemortem dengan tampilan geometris yang sama, faktor eksposur yang sesuai, dan pengolahan arsip.

3. Penggunaan sistem penandaan atau pemasangan film radiograf gigi antemortem dan postmortem dapat dibedakan.

4. Analisis radiograf secara visual dengan mempertimbangkan informasi tambahan yang terdapat pada rekam medis seperti odontogram, model gigi atau foto klinis.

5. Penjumlahan poin kesamaan dan perbedaan di antara radiograf antemortem dan postmortem.

6. Pengambilan keputusan untuk 


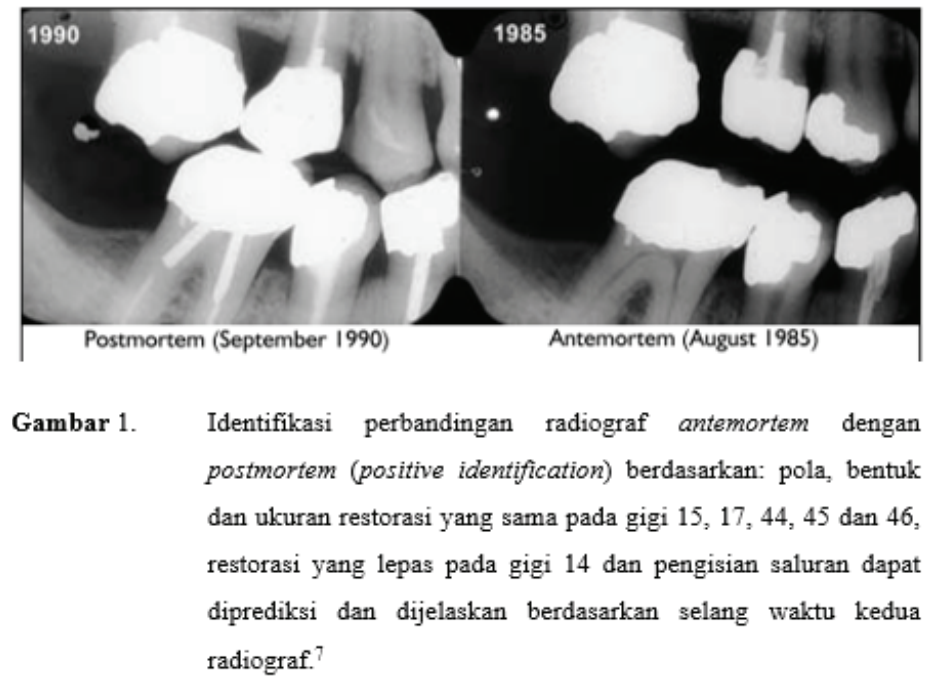

penarikan kesimpulan akhir.

Penarikan kesimpulan dalam identifikasi didasarkan pada ketetapan American Board of Forensic Odontology (ABFO) yaitu positive identification, possible identification, insufficient evidence dan exclusion. Positive identification adalah saat data antemortem cocok dengan data postmortem dengan detil yang cukup dan tidak terdapat perbedaan yang tidak dapat dijelaskan, sehingga dapat ditetapkan kedua data berasal dari individu yang sama. Possible identification adalah saat data antemortem cocok dengan postmortem namun dikarenakan kualitas data postmortem atau antemortem yang kurang baik, positive identification tidak mungkin untuk ditetapkan. Insufficient evidence adalah saat positive identification tidak dapat disimpulkan karena tidak terdapat cukup informasi. Exclusion adalah saat perbedaan yang ada tampak jelas pada data antemortem dengan postmortem $3,7,18$.

\section{KESIMPULAN}

Identifikasi terhadap jenazah yang tidak diketahui identitasnya wajib dilakukan. Identifikasi perbandingan tampilan khas gigi antemortem dengan postmortem yang dilakukan menggunakan radiograf gigi dinilai akurat.

\section{DAFTAR PUSTAKA}

1. Zakirulla M, Allahbaksh M. Modern Tools in Forensic Dentistry. Int J Contemp Dent. 2011;2(3):28-33.

2. Patil N, Karjodkar FR, Sontakke S, Sansare K, Salvi R. Uniqueness of Radiographic Patterns of The Frontal Sinus for Personal Identification. Imaging Sci Dent. 2012;42(4):213-7. doi:10.5624/ isd.2012.42.4.213

3. Kolude D, Adeyemi B. F., Taiwo J. O., Sigbeku O.F. EUO. The Role of Forensic Dentist Following Mass Disaster. Ann Ibadan Postgrad Med. 2010;8(2):111117.

4. Thimmarasa VB, Devi P, Jayadev S. Role of Dentomaxillofacial Radiography in Forensic Odontology : a Review. J Oral Sign. 2010;2(1):1-5.

5. Singh K, Anandani C, Kaur Bhullar R. Teeth and Their Secrets - Forensic Dentistry. J Forensic Res. 2012;03(01):9-11. Available at: http://www. omicsonline.org/2157-7145/2157-7145-3-141. digital/2157-7145-3-141.html. Accessed June 5, 2014.

6. Henky, Safitry O. Identifikasi Korban Bencana 
Massal : Praktik DVI Antara Teori dan Kenyataan. Indones J Leg Forensic Sci. 2012;2(1):5-7.

7. Pretty IA, Sweet D. A Look at Forensic Dentistry Part 1: The Role of Teeth in The Determination of Human Identity. Br Dent J. 2001;190(7):359-366.

8. Prawestiningtyas E, Algozi AM. Forensic Identification Based on Both Primary and Secondary Examination Priority in Victim Identifiers on Two Different Mass Disaster Cases. J Kedokt Brawijaya. 2009;25(2):87-94.

9. Pittayapat $P$, Jacobs R, Valck E De, Vandermeulen D, Willems G. Forensic Odontology in The Disaster Victim Identification Process. J Forensic Odontostomatol. 2012;30(1):1-12.

10. Ferreira R, Nunes FG, Camilo J, et al. Forensic Importance of Panoramic Radiographs for Human Identification. Rev Gaúcha Odontol. 2012;60(4):527531.

11. Panchbhai A. Dental Radiographic Indicators, a Key to Age Estimation. Dentomaxillofac Radiol. 2011;40(4):199-212. doi:10.1259/dmfr/19478385.

12. Devi P, B T V, Mehrotra V, Singla V. Automated Dental Identification System: An Aid to Forensic Odontology. J Indian Acad Oral Med Radiol. 1997;23(3):5360-5364.
13. Brogdon BG. Forensic Radiology. Florida: CRC Press LLC; 1998:Chapter 6.

14. Akarslan ZZ, Akdevelioğlu M, Güngör K, Erten H. A Comparison of The Diagnostic Accuracy of Bitewing, Periapical, Unfiltered and Filtered Digital Panoramic Images for Approximal Caries Detection in Posterior Teeth. Dentomaxillofac Radiol. 2008;37(8):458-463. doi:10.1259/dmfr/84698143.

15. Williamson GF. Best Practices in Intraoral Digital Radiography. www.rdhmag.com. 2011:80-87.

16. Affairs S. The Use of Dental Radiographs.; 2006:1304-1312.

17. White SC, Pharoah MJ. Oral Radiology: Principle and Interpretation. 7th ed. St. Louise: Mosby; 2014:78-81, 86-89, 152-156.

18. Pallagatti S, Sheikh S, Aggarwal A, Gupta RSD, Kaur A. Maxillofacial Imaging: An Emerging Tool in Forensic Science. J Forensic Res. 2011;2(6):2-4. doi:10.4172/2157-7145.1000134. 